\title{
Pretreated rice straw as an improved fodder for ruminants-An overview
}

\author{
Kamla Malik $^{1 *}$, Jayanti Tokkas², Ramesh Chander Anand ${ }^{1}$ and Nisha Kumari \\ ${ }^{1}$ Department of Microbiology, College of Basic Sciences and Humanities, Chaudhary Charan Singh Haryana \\ Agricultural University, Hisar-125 004, INDIA \\ ${ }^{2}$ Department of Biochemistry, College of Basic Sciences and Humanities, Chaudhary Charan Singh Haryana \\ Agricultural University Hisar-125 004, INDIA \\ *Corresponding author. E-mail: kamlamalik@rediffmail.com
}

Received: September 15, 2014; Revised received: January 30, 2015; Accepted: March 9, 2015

\begin{abstract}
Rice straw, a by-product of the rice production is mainly used as a source of feed for ruminant livestock is the major forage in rice-producing areas in India. The disposal of the rice straw is a serious problem in areas where it is the major agricultural product. It is rich in polysaccharides and has a high lignin and silica content, limiting voluntary intake and reducing degradability by rumen microbes. By rice straw treatment, its quality and digestibility can be improved and enhanced the protein content. Several methods have been used to improve the utilization of rice straw by ruminants or supplemented by other ingredients to increase digestibility and nutrient value before it can be considered a suitable animal feed. In recent years, biological treatments have been investigated for improvement in nutritional value of rice straw. The use of ligninolytic fungi and their extracellular ligninolytic enzymes for treatment of rice straw results in degrading cellulose and hemicelluloses contents which improve its nutritional value. The use of fungi and enzyme treatments is expected to be a practical, cost-effective and environmental-friendly approach for enhancing the nutritive value and digestibility of rice straw. Therefore, the treated rice straw has a good potential as feed for ruminants.
\end{abstract}

Keywords: Cattle, Feed, Nutritive value, Rice straw, Utilization

\section{INTRODUCTION}

A large numbers of animals are suffering from shortage of feeds both in quality and quantity. The available roughage and concentrate for feeding livestock can meet only 50 and $10 \%$ respectively of the requirement. Rice straw alone contributes $87 \%$ of the roughage feed of animals (Haque et al., 2007). Rice straw is the vegetative part of the rice plant (Oryza sativa L.), cut at grain harvest or after. Rice straw is a versatile by-product of rice cultivation as it is used in many ways including fodder for livestock and even as a building material. However, the increase in productivity and size of paddy areas, among other things, has led to a huge excess of rice straw where the most cost-effective way of disposing of the residue is seen as burning the biomass in the paddy field (Kadam et al., 2000).

Now-a-days, there is global concern on human activities such as burning of wastes or refuse with the view of reducing impact of burning on ozone layer depletion. Such global concern, therefore, necessitated alternative option or method for recycling of waste or residues into beneficial products. The possibility of recycling rice straw into value added products then comes into view (Akinfemi and Ogunwole, 2012). It may be burned and left on the field before the next ploughing, ploughed down as soil improver or used as a feed for livestock (Kadam et al., 2000). Although rice straw produced every year is plentiful, the amount a ruminant can consume is not sufficient to sustain a reasonable level of production due to its low nutritive value. Therefore, rice straw has not been maximally utilized for ruminant production yet. It may be fed as part of the roughage component of the diet to cattle. The value of rice straw to bovines is limited by low voluntary intake, slow rate of digestion and low content of available energy, protein, minerals and vitamins (Van Soest, 2006). Extensive research has been carried out for several decades on improving nutritive value of cereal straws for livestock using physical, chemical and biological treatments and varying degree of success has been reported (Vadiveloo, 2003; Selim et al., 2004; Sarnklong, et al., 2010). However, economic benefit and social acceptance of these technologies is limited (Devendra, 1997). Pre-treatment of straw is one of the possible alternatives for better utilization and improves the digestibility of straw. Different treatment procedures are available to upgrade the nutritive value of straws (Doyle et al., 1996). The nutritional value of rice straw can be upgraded by different methods. Physical, chemical (Sarwar et al., 2004a; 2004b) and biological treatments have been used to weaken and break down ligno-cellulose bonds in crop residues, thereby increasing their feeding value for ruminants. In India, burning of straw is the major method for disposal that causes 
atmospheric pollution and nutrient loss. Rice straw has poor digestibility and low nutritive value. So ruminants have limited its use as feed. The possible alternative for better utilization of straw is to improve its digestibility through treatment with appropriate chemical or biological agents or by physical means so that its lignocellulose bond is broken or at least loosened to free major portion of cellulose to be digested by the cattle (Rahman, et $a l ., 2010)$. The aim of this paper provides an overview of the utilization of rice straw as a feed for ruminants and highlights some techniques have been used to improve the utilization of rice straw as feed.

\section{CHARACTERISTICS OF RICE STRAW}

Chemical composition and nutritive quality of rice straw: Rice straw is one of the most abundant lignocellulosic waste materials in the world. It contains $32-43 \%$ cellulose, $19-25 \%$ hemicellulose, $5-12 \%$ lignin, $18.8 \%$ ash (14-16\%) and extractives (10-12\%) (Yoswathana and Phuriphipat, 2010). The compositions of rice straw are shown in Table 1. India is the second largest producer of rice in the world after China and has 30,000 varieties of paddy crops (Goh, et al., 2010). The structural complexity of rice straw due to the presence of lignin is a major constraint for enzymatic and microbial attacks (Balasubramanian, 2013). The lignin component acts as a physical barrier and must be removed to make the carbohydrates available for further hydrolysis process. Lignin provides structural support to the plant, impermeability and resistance to degradation. To break down these components cellulase, hemicellulase and ligninase enzymes are required (Schiere and Ibrahim, 1989). These enzymes are not produced by the animals themselves but the reticulo rumen of ruminants maintains microorganisms that do produce cellulase and hemicellulase. However, lignin cannot be broken down in the rumen due to the lack of ligninase. Even if lignin could be degraded in the rumen it would not provide much energy to the animals. Lignin, however, has important effects on livestock production by effecting degradability and feed intake (Vadiveloo, 2000).

The chemical composition of rice straw varies between varieties and growing seasons, with higher nitrogen and cellulose contents in early-season rice compared to others (Shen et al., 1998). The level of phosphorus in rice straw is less than the level of about 0.3 percent that animals need for growth and normal fertility. A level of about 0.4 percent of calcium in the diet is usually considered adequate for livestock, and many samples of rice straw have this amount. Rice straw contains high levels of oxalates (1-2 \% dry matter (DM). Rice straw also differs from other straws in having a high (1-2 percent) content of oxalates. These are broken down in the rumen to carbonates and bicarbonates, absorbed, and then excreted in the urine.

\section{METHODS FOR RICE STRAW TREATMENT TO IMPROVE THE FEED VALUE}

Rice straw is a by-product of the rice grain industry. It is a potential alternative feed for cattle due to burning of rice straw. It has limited nutritive value (low crude protein, palatability digestibility and high oxalates). It should be used only as a replacement for part of the forage in a ration. To improve the use of crop residues for ruminants is to overcome the barriers to rumen microbial fermentation of lignocellulosics. In rice straw, the important factors that restrict bacterial digestion in the rumen are its high level of lignification and silicification, the slow and limited ruminal degradation of the carbohydrates and the low content of nitrogen, minerals and vitamins that affect its value as feed for ruminants (Van Soest, 2006). To improve the feeding value of rice straw, the straw can be treated with different methods in order to improve its nutritive value, enhance feed intake and digestibility. Methods of treating straw may be classified broadly into mechanical, physical, chemical and biological categories. Several studies have reported the physical, chemical characterization and utilization of rice straw as ruminant feed (Abou-El-c Enin et al., 1999; Vadiveloo, 2003). Other methods have also been investigated, including supplementation with other feed stuffs or components in order to improve the utilization of rice straw by ruminants ( $\mathrm{Vu}$ et al., 1999; Selim et al., 2004). Different uses of rice straw as compost, for pulp and paper, construction materials, soil incorporation, fuel etc by using different methods (Table 2). The utilization of rice straw by ruminants is possibly the most efficient means of conversion of this residue to overcome problems of pollution through slow breakdown or burning.

Mechanical treatment: Chopping and grinding of rice straw may reduce the time of passage in the rumen and improve feed for ruminants (Doyle et al., 1996).

Physical treatment: The mainly used physical methods are grinding and pressure cooking process (Fig. 1), very fine grinding in ball mills. With all-roughage diets, grinding causes an increase in intake and weight gain. These effects are greater for roughages with lower digestibility and nitrogen can be a limiting factor for improvement by grinding of very poor roughages like straw. Grinding usually decreases digestibility, but at the same time increases the net energy value of the straw somewhat because the nutrients that are digested are utilized more efficiently by the animal (Selim et al., 2004). Crop residues can be ground, soaked, pelleted or chopped to reduce particle size or can be treated with steam or X-rays or pressure cooked. Many of these treatments are not for practical use on small-scale farms, as they require machines or industrial processing. This makes these treatments economically unprofitable for farmers as the benefits may be low (Schiere and Ibrahim, 1989). However, small machines to grind or chop rice straw may be feasible.

Chemical treatment: Chemicals used to improve the 
rice straw utilization are alkaline, acidic or oxidative agents (Fig. 1). Among these, alkaline agents have been most widely accepted for application on farms. These alkaline agents can be absorbed into the cell wall and chemically broke down the ester bonds between lignin, hemicellulose and cellulose, and physically make the structural fibers swollen (Chenost and Kayouli, 1997). These effects enable the rumen microorganisms to attack more easily the structural carbohydrates, enhancing degradability and palatability of the rice straw (Selim et al., 2004). The most commonly used alkaline agents are sodium hydroxide $(\mathrm{NaOH})$, ammonia $\left(\mathrm{NH}_{3}\right)$ urea, chlorine and lime. Chemical treatments appear to be the more practical for use on-farms, as no expensive machinery is required. These are relatively cheap and the simple procedures are used. However, the chemicals are not harmless and safety precautions are needed for their use. As rice straw is poorly fermented, it has low rates of disappearance in the rumen and low rates of passage through the rumen, reducing feed intake. Various chemical treatments were conducted to increase the utilization of rice straw as feed for ruminant animals (Shen et al., 1999; Selim et al., 2004).

Various sources of protein, minerals and energy should be added to improve the nutritive value of feeds. By treating rice straw with urea or calcium hydroxide or by supplementing rice straw with protein, intake, degradability and milk yield can be enhanced, compared to feeding untreated rice straw alone (Fadel Elseed, 2005; Wanapat et al., 2009). Sarnklong et al. (2010) studied the effect of chemical treatment on the ruminal fermentation products in cattle. Unconventional alkali treatment made from filtrate of a $10 \%$ rice hulls ash solution enriched with urea and minerals increased volatile fatty acid (VFA) production, ammonia nitrogen $\left(\mathrm{NH}_{3}-\mathrm{N}\right)$ and rumen microbial protein synthesis (MPS). The maximum values of $\mathrm{NH}_{3}-\mathrm{N}$ production and rumen microbial protein synthesis were reached at 4 hours after incubation, while VFA reached at 6 hours. Another experiment was conducted to study the increase in nutritive value of rice straw through supplementation with various protein sources like residues of vegetative oil production such as coconut, peanut and soybean which showed higher responses compared to soy-sauce and tofu making residue. The protein effluent production was highest $(2.19 \mathrm{~g} / \mathrm{d})$ at a VFA/ $\mathrm{NH}_{3}-\mathrm{N}$ ration of $37.74(\mathrm{r}=0.912)$. It has been recommended that protein sources from agro-industrial wastes can be used to increase the nutritive value and utilization of rice straw as ruminant feed (Suwandyastuti and Bata, 2010).

Biological treatment: The biological methods of rice straw treatment have great potential in comparison to the use of expensive chemicals. Pollution would also be reduced. It may promise a new horizon for research in a developing country. The organism grown on the straw must obtain its energy from the straw itself and degrade cellulose and hemicelluloses. Successful biological treatment must be based upon the use of organism which degrades lignin. The use of fungi and enzymes that metabolize lignocelluloses is a potential biological treatment to improve the nutritional value of straw by selective delignification. With recent developments in fermentation technology and alternative enzyme production system, the cost of these materials is expected to decline in future (Liu and Orskov, 2000). Hence, new commercial products could play important role in future ruminant production systems (Beauchemin et al., 2004). In biological pretreatment processes, micro-organisms such as brown, white and soft rot fungi are used to degrade lignin and hemi-cellulose in waste materials (Fig. 1). Advantages of biological pretreatment include cost effectiveness, low energy requirement and mild environmental conditions. Most of the white-rot fungi degrade lignin and cellulose simultaneously. White-rot fungi, belonging to the wood-decaying basidiomycetes, as lignocellulolytic microorganisms are able to decompose and metabolize all plant cell constituents (cellulose, hemicellulose and lignin) by their enzymes (Eriksson et al., 1990). Many species of white-rot fungi which are effective lignin degraders have been used to assess their ability to improve the nutritive value of fodder for ruminant nutrition (Howard et al., 2003).

The commercially available exogenous fiber-degrading enzyme products consist of cellulases and xylanases, as produced for non-feed applications. Commercial enzymes used in the livestock feed industry are of fungal (Trichoderma longibrachiatum, Aspergillus niger, A. oryzae) and bacterial origin. Enzyme treatment alone or in combination with other treatments can increase the degradability of cereal straw by the rumen microorganisms (Wang et al., 2004; Rodrigues et al., 2008). Application of enzymes has proven to increase the feed value of poor quality feedstuffs; its use by smallholder farmers is, for the time being, economically unattractive. The nutritive value of rice straw treated with three different edible mushrooms: Pleurotus ostreatus (POR), Pleurotus pulmonarius (PPR) and Pleurotus tuber-regium (PTR) were studied through analysis of their proximate composition, mineral composition, crude fiber fractions and in vitro digestibility. It was observed that treatment of rice straw with different edible mushrooms improved the potential feeding value. Therefore, the product of fungal treatment has a good potential as feed resources for ruminants (Akinfemi and Ogunwole, 2012).

Feeding rice straw supplemented with other components: The supplementation of effective components which are locally available should be a strategy for better utilization of rice straw. Rice straw is low in nitrogen and difficult to degrade, it is obvious that supplementation of rice straw with a protein source and a more easily accessible energy source will improve the performance and production of the animals. Supplementation of rice straw with protein, energy and/or minerals may optimize rumen function, also maximizing utilization of the rice straw and increasing intake. Chenost and Kayouli (1997) studied that, it is necessary to provide the rumen 
Table 1. Composition of rice straw.

\begin{tabular}{lc}
\hline Components & $\begin{array}{c}\text { Percent dry } \\
\text { weight }\end{array}$ \\
\hline Cellulose & 43 \\
Hemicellulose & 25 \\
Lignin & 12 \\
Digestible energy, mcal/kg & 1.9 \\
Ash & 16 \\
Dry matter & $90 \%$ \\
Total digestible nutrients (TDN) & 44.0 \\
Crude protein & 4.5 \\
Calcium & 0.4 \\
Phosphorous & 0.08 \\
Total nitrogen & 0.67 \\
Potassium & 1.2 \\
Sulphur & 0.04 \\
Fat & 1.0 \\
Magnesium & 0.11 \\
Silica & 15.8 \\
Crude fiber & 29.8 \\
\hline
\end{tabular}

Source: Kargbo, et al., 2009; Sarnklong, et al., 2010; Akinfemi, A. and Ogunwole, 2012

microbes with the nutritive elements which they need for self-multiplication and for degradation of the cell walls of straw, and to ensure all conditions for maintenance of good cellulolysis. Different supplements can be used such as urea, molasses, green leaves, multi-nutrient blocks, crop residues and locally available by-products. The rice straw supplemented with soybean meal increased both degradability and intake. Untreated rice straw, supplementation can easily increase milk production when supplemented with cottonseed meal and with urea, molasses- multi-nutrient block (Vu et al., 1999; Akter et al., 2004). Suitable treatment techniques in combination with nutrient supplementation could result in improved utilization of rice straw and better feeding value.

\section{FACTORS AFFECTING THE DIGESTIBILITY OF STRAW}

The quality and digestibility of straw is depend upon different factors as follows: Intrinsic factors such as variety, time between harvest and storage, $\mathrm{N}$ fertilization, plant maturity (lignin content increases with maturity), plant health and weather conditions (Drake et al.,
2002). Rice straw is a good source of energy, but is poor in protein (2-7\%) and its high silica content results in a low digestibility. It is considered as a low quality and variable roughage (Doyle et al., 1996), high NDF (neutral detergent fiber) content resulting in poor dry matter intake and low fat that effect on milk yield and low content in $\mathrm{P}, \mathrm{Cu}, \mathrm{Zn} \mathrm{Ca}$ and $\mathrm{NaCl}$ that do not meet animal requirements (Kanjanapruthipong, et al., 2006). The way the straw is fed to animals (diet composition and level of feeding). When straws are fed to ruminants, the primary limitations to production are low overall digestibility, slow rate of passage in the rumen, low propionate fermentation pattern in the rumen, and low contents of fermentable $\mathrm{N}$ and by-pass protein. The environmental conditions such as light, temperature, soil moisture, fertilizers on chemical compositions are effect on digestibility of straw. The harvested (height of cutting), morphological fractions (leaves, stems etc) threshing and storage methods are also effect on the digestibility of straw (Heuze and Tran, 2013).

\section{BENEFIT OF TREATED RICE STRAW}

Straw has the nutritional characteristics of being rich in energy, low in crude protein, and poor in palatability due to poor-quality roughage that sway requires proper pretreatment or supplementation with other nutrients before it can be used as useful feed for ruminants. If straw is used as the primary feed for animals, such as for the maintenance of animals, it must be supplemented with protein, phosphorus, calcium, and some trace minerals. The feed value of straw varies with the type, variety, and botanical parts of straw. The straw consists of polysaccharides, such as cellulose and hemicelluloses. Even though straw contains enough cellulose to make it an excellent source of dietary energy for ruminants, it is a poor-quality feed in its natural state because of low digestibility and protein content, poor palatability, and bulkiness. Various pretreatment processes, including physical, chemical and biological are used to increase the acceptability of straw to animals, thus increasing daily feed intake, and to enhance the rate of digestion and increasing the availability of nutrients. The nutritive value of straws can be improved in several ways. Treatment with chemicals, such as alkali, acid that alters the characteristics of straws and renders the cell-wall constituents more susceptible to microbial attack and thus increases

Table 2. Usage of straw.

\begin{tabular}{ll}
\hline Methods & Products \\
\hline Direct uses & Mulch, fertilizer, soil conditioner, fuel, feed, packaging materials, bedding for animals \\
Mechanical conversion & Densified straw, pulp and paper, particle board, etc. \\
Chemical conversion & $\begin{array}{l}\text { Alcohol, sugar, furfural, cellulose derivatives, lignin, resins, phenolic compounds, } \\
\text { xylitol, plastics, esters, etc. }\end{array}$ \\
Physical conversion & $\begin{array}{l}\text { cellulose derivatives, sugars, enzymes, etc. } \\
\text { Biological conversion }\end{array}$ \\
& $\begin{array}{l}\text { Single cell protein, alcohol, sugar, compost, silage, methane, fermented feed, } \\
\text { enzyme,etc. }\end{array}$ \\
\hline
\end{tabular}




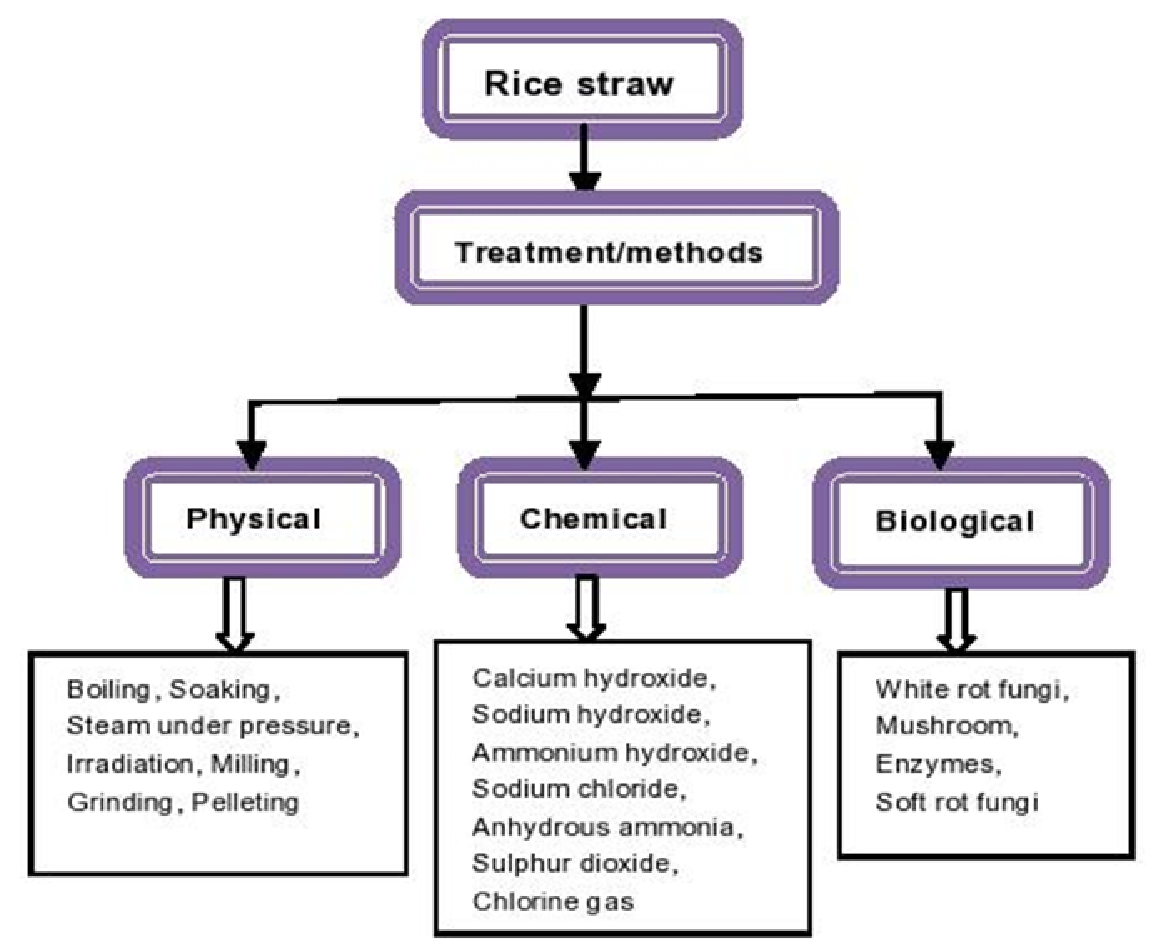

Fig.1. Different methods of rice straw for improving the efficiency for feed value Source: Sarnklong, et al., 2010; Ibrahim, 1983

straw intake and digestibility. Supplementation with limiting nutrients can also improve straw utilization. Effects of treating rice straw with urea and calcium hydroxide upon intake, digestibility, rumen fermentation and milk yield of dairy cows increased. These alkaline agents can chemically break the ester bonds between lignin, hemicelluloses and cellulose, and physically make structural fibers swollen; hence higher rate of digestibility (Wanapat et al., 2009).Untreated straw may support only the feed requirements of the ruminants. Treated straw with supplements can support to increase in digestibility and intake efficiency (Chenost and Kayouli, 1997). Biologically treated (with ligninolytic fungi) roughages have higher digestibility for most of the nutrients (both cell walls and cell soluble) with an increase in crude protein content as compared to untreated material, besides ensuring more fermentable substrates in the rumen. These feedstuffs are subjected to solid state fermentation (SSF) as a result of their improved digestion and nutrient assimilation (Mahesh and Mohini, 2013). Overall; these treatments have increased palatability, daily feed intake, nutritive value and maintained the health quality of ruminants as compared to untreated rice straw.

\section{Conclusion}

Ruminant production has had and will continue to play a very important role in India. A large proportion of the rice straw produced is not fed to livestock. However, its further development is confronted with major problems related to the scarcity of grazing and low quality of crop residues which are the major sources of available feed for ruminant. It was concluded that the use of ligninolytic fungi and their extracellular ligninolytic enzymes for treatment of rice straw results in degrading cellulose and hemicelluloses contents which improve its nutritional value. The use of fungi and enzyme treatments is expected to be a practical, cost-effective and environmental-friendly approach for enhancing the nutritive value and digestibility of rice straw.

\section{ACKNOWLEDGEMENT}

We thank the Indian Council of Agricultural Research (ICAR) for financial support under All India Coordinated Research Project (AICRP). We also thank the Head, Department of Microbiology, COBS\&H, CCS HAU, Hisar for encouragement and technical support

\section{REFERENCES}

Abou-El-c Enin, O.H., Fadel, J.G. and Mackill, D.J. (1999). Differences in chemical composition and fibre digestion of rice straw with, without, anhydrous ammonia from 53 rice varieties. Animal Feed Science and Technology 79: 129-136.

Akinfemi, A. and Ogunwole, O.A. (2012). Chemical composition and in vitro digestibility of rice straw treated with Pleurotus ostreatus, Pleurotus pulmonarius and Pleurotus tuber-regium. Slovak Journal of Animal Sciences 45: $14-20$.

Akter, Y., Akbar, M.A., Shahjalal, M. and Ahmed, T.U. (2004). Effect of urea molasses multi-nutrient blocks supplementation of dairy cows fed rice straw and green grasses on milk yield, composition, live weight gain of cows and calves and feed intake. Pakistan Journal of Biological. Sciences 7: 1523-1525.

Balasubramanian, M.K. (2013). Potential utilization of rice straw for ethanol production by sequential fermentation of cellulose and xylose using Saccharomyces cerevisiae and Pachysolen tannophilus. International Journal of Science, Engineering, Technology and Research 2: 
1531-1535.

Beauchemin, K.A., Colombatto, D. and Morgavi, D.P. (2004). A rationale for the development of feed enzyme products for ruminants. Canadian Journal of Animal Sciences 84: 23-36.

Chenost, M. and Kayouli, C. (1997). Roughage utilization in warm climates. FAO Animal Production and Health, Rome.

Devendra, C. (1997). Crop residues for feeding animals in Asia: Technology development and adoption in crop/ livestock systems. In: Crop Residuals in Sustainable Mixed Crop/livestock Farming System (Ed. C. Renard). CAB International; Wallingford, UK. pp241-267

Drake, D.J., Nader, G. and Forero, L. (2002). Feeding rice straw to cattle. Publication 8079 - University of California, Division of Agriculture and Natural Resources. California.

Doyle, P.T., Devendra, C. and Pearce, G.R. (1996). Rice straw as a feed for ruminants. International Development Program of Australian Universities and Colleges Limited (IDP), Canberra, Australia.

Eriksson, K.L., Blanchette, R.A. and Ander, P. (1990). Microbial and enzymatic degradation of wood and wood components. Springer, Berlin, Heidelberg, New York.

Fadel Elseed, A.M.A. (2005). Effect of supplemental protein feeding frequency on ruminal characteristics and microbial $\mathrm{N}$ production in sheep fed treated rice straw. Small Ruminant Research 57: 11-17.

Goh, C.S., Tan, K.T., Lee, K.T. and Bhatia, S. (2010). Bioethanol from lignocelluloses: status, perspectives and challenges in Malaysia. Bioresource Technology 101: 4834-4841.

Haque, Q.M.E., Amanullah, S.M. and Islam, M.M. (2007). Introduction of forage crops with the existing cropping system of different agro-ecological zones of Bangladesh and its impact analysis. Progress Report, Anim. Production Division, BLRI.

Heuze, V. and Tran, G. (2013). Rice straw. Feedipedia. Org. A programme by INRA, CIRAD, AFZ and FAO( http:// www.feedipedia.org/node/557).

Howard, R., Abotsi, E.E., Jansen, L. and Howard, S. (2003). Lignocellulose biotechnology: Issues of bioconversion and enzyme production. African Journal of Biotechnology 2: 602-619.

Kadam, K.L., Forrest, L.H. and Jacobson, W.A. (2000). Rice straw as a lignocellulosic resource: collection, processing, transportation, and environmental aspects. Biomass and Bioenergy 18: 369-389.

Kargbo, F.R., Xing, J. and Zhang, Y. (2009). Pretreatment for energy use of rice straw: a review. African Journal of Agricultural Research 4: 30-40.

Kanjanapruthipong, J. and Thaboot, B. (2006). Effects of neutral detergent fiber from rice straw on blood metabolites and productivity of dairy cows in the tropics. Asian-Australian Journal of Animal Science 19: 356-362.

Liu, J.X. and Orskov, E.R. (2000). Cellulase treatment of untreated and steam pre-treated rice straw-effect on in vitro fermentation characteristics. Animal Feed Science and Technology 88: 189-200.

Mahesh, M.S. and Mohini, M. (2013). Biological treatment of crop residues for ruminant feeding: A review. African Journal of Biotechnology 12: 4221-4231.

Nader, G. (2000). Rice straw utilization by cattle. Report to the Rice Research Board. December. http://www. syix. com/rrb/00rpt/StrawCattle.htm

Rahman, M.M., Akbar, M.A., Islam, K.M.S., Khaleduzzaman, A.B.M. and Bostami, A.B.M.R. (2010). Nutrient digestibility and growth rate of bull calves fed rice straw treated with wood ash extract. Bangladesh Journal of Animal Science 39: 97-105.

Rodrigues, M.A.M., Pinto, P., Bezerra, R.M.F., Dias, A.A., Guedes, C.V.M., Gardoso, V.M.G.W., Colaco, L.M.M. J. and Sequeira, C.A. (2008). Effect of enzyme extracts isolated from white-rot fungi on chemical composition and in vitro digestibility of wheat straw. Animal Feed Science and Technology 141: 326-338.

Sarnklong, C., Cone, J.W., Pellikaan, W. and Hendriks, W.H. (2010). Utilization of rice straw and different treatments to improve its feed value for ruminants: A review. Asian-Australian Journal of Animal Science 23: $680-692$.

Sarwar, M., Khan, M.A. and Nisa, M. (2004a). Effect of organic acids of fermentable carbohydrates on digestibility and nitrogen utilization of urea treated wheat straw in buffalo bulls. Australian Journal of Agricultural Research 55: 223-228.

Sarwar, M., Khan, M.A. and Nisa, M. (2004b). Influence ruminally protected fat and urea treated corncobs on nutrient intake, digestibility, milk yield and its composition in Nili-Ravi buffaloes. Asian-Austral. Journal of Animal Science 17:171-176.

Schiere, J.B. and Ibrahim, M.N.M. (1989). Feeding of urea ammonia treated rice straw: A compilation of miscellaneous reports produced by the straw utilization project, Pudoc, Wageningen, Sri Lanka.

Selim, A.S.M., Pan, J., Takano, T., Suzuki, T., Koike, S., Kobayashi, Y. and Tanaka, K. (2004). Effect of ammonia treatment on physical strength of rice straw, distribution of straw particles and particle-associated bacteria in sheep rumen. Animal Feed Science and Technology 115: $117-128$.

Shaver, R. and Hoffman, P. (2010). Use of straw in dairy cattle diets. Focus on Forage, 12: 2-10.

Shen, H.S., Ni, D.B. and Sundstol, F. (1998). Studies on untreated and urea-treated rice straw from three cultivation seasons: Physical and chemical measurements in straw and straw fractions. Animal Feed Science and Technology 73: 243-261.

Shen, H.S., Sundstol, F. and Eik, L.O. (1999). Studies on untreated and urea-treated rice straw from three cultivation seasons: 3. Histological investigations by light and scanning electron microscopy. Animal Feed Science and Technology 80: 151-159.

Suwandyastuti, S.N.O. and Bata, M. (2010). Improvement of rice straw for ruminant feed through conventional alkali treatment and supplementation of various protein sources. Journal of Animal Production 12: 82-85.

Vadiveloo, J. (2003). The effect of agronomic improvement and urea treatment on the nutritional value of Malaysian rice straw varieties. Animal Feed Science and Technology 108: 33-146.

Van Soest, P.J. (2006). Review: rice straw, the role of silica and treatments to improve quality. Animal Feed Science and Technology 130: 137-171.

Vu, D.D., Cuong, L.X., Dung, C.A. and Hai, P.H. (1999). Use of urea-molasses-multi-nutrient block and urea-treated rice straw for improving dairy cattle productivity in Vietnam. Preventive. Veterinary Medicine 38: 187-193.

Wanapat, M., Polyrach, S., Boonnop, K., Mapato, C. and Cherdthong, A. (2009). Effect of treating rice straw with urea and calcium hydroxide upon intake, digestibility, 
rumen fermentation and milk yield of dairy cows. Livestock Science 125: 238-243.

Wang, Y., Spratling, B.M., ZoBell, D.R., Wiedmeier, R.D. and McAllister, T.A. (2004). Effect of alkali pretreatment of wheat straw on the efficacy of exogenous fibrolytic enzymes. Journal of Animal Science 82: 198-208.
Yoswathana, N. and Phuriphipat, P. (2010). Bioethanol production from rice straw. Energy Research Journal 1: 26-31.

Vadiveloo, J. (2000). Nutritional properties of the leaf and stem of rice straw. Animal Feed Science and Technology 83: 57-65. 